\title{
GERMINATION AND GROWTH OF Fimbristylis miliacea BIOTYPES Resistant and Susceptible to ACETolactate Synthase-Inhibiting HERBICIDES ${ }^{1}$
}

\author{
Germinação e Crescimento de Biótipos de Fimbristylis miliacea Resistente e Suscetível aos \\ Herbicidas Inibidores da Enzima Acetolactato Sintase
}

SCHAEDLER,C.E. ${ }^{2}$, NOLDIN, J.A. ${ }^{3}$, AGOSTINETTO, D. ${ }^{4}$, DAL MAGRO, T. ${ }^{5}$, and FONTANA, L.C. ${ }^{6}$

\begin{abstract}
Weed biotypes resistant and susceptible to herbicides may have differences in their adaptive values. The aims of this study were to compare, under controlled and noncompetitive condition, the growth analysis, germination features and seed weight of Fimbristylis miliacea (FIMMI) biotypes resistant and susceptible to acetolactate synthase (ALS) inhibiting herbicides. Experiments were conducted in a greenhouse and in a laboratory from October 2008 to February 2010. Two resistant biotypes (FIMMI 10 and FIMMI 12) and one susceptible biotype (FIMMI 13) were used for the studies. For the study on growth analysis, the treatments were arranged in a completely randomized experimental design with four replications and sampled at 21, 28, 35, 42, 49, 56, 69 days after emergence (DAE) and at flowering stage. For the studies on germination speed, germination and seed weight, the indexes for germination speed, percentage of germination at different temperatures and seed weight of the biotypes were determined. The results showed that the resistant biotype FIMMI 12 shows differences in all variables compared to the resistant biotype FIMMI 10 and compared to the susceptible biotype FIMMI 13, only for the evaluation at flowering. The susceptible biotype FIMMI 13 showed a higher germination speed index and higher germination rate when compared with the resistant biotypes. On the other hand, the resistant biotypes FIMMI 10 and FIMMI 12 showed higher seed weight.
\end{abstract}

Keywords: paddy rice, globe fringerush, Oryza sativa, herbicide resistance.

RESUMO - Biótipos de plantas daninhas suscetiveis e resistentes a herbicidas podem apresentar diferenças quanto ao seu valor adaptativo. Os objetivos deste trabalho foram comparar, em condição controlada e não competitiva, a análise de crescimento, características de germinação e peso de sementes de biótipos de Fimbristylis miliacea resistente e suscetivel a herbicidas inibidores da ALS. Experimentos foram conduzidos em casa de vegetação e em laboratório no periodo de outubro de 2008 a fevereiro de 2010. Para os estudos foram utilizados dois biótipos resistentes (FIMMI 10 e FIMMI 12) e um suscetivel (FIMMI 13). No estudo de análise de crescimento, os tratamentos foram organizados em delineamento completamente casualizado com quatro repetições e oito épocas de coletas [21, 28, 35, 42, 49, 56, 69 dias após a emergência (DAE) e no florescimento]. Quanto aos estudos de velocidade de germinação, germinação e peso de sementes, foram determinados os indices de velocidade de germinação, porcentagem de germinação em diferentes temperaturas e peso de sementes dos biótipos. Os resultados demonstraram que o biótipo resistente FIMMI 12 apresentou diferença em todas as variáveis avaliadas em comparação ao biótipo resistente FIMMI 10 e, em comparação ao suscetivel FIMMI 13, apenas no florescimento. O biótipo suscetivel FIMMI 13 apresentou maior índice de velocidade de germinação e maior germinação em porcentagem quando comparado com os biótipos resistentes. Por outro lado, os biótipos resistentes FIMMI 10 e FIMMI 12 apresentaram maiormassa de sementes.

Palavras-chave: arroz irrigado, cuminho, Oryza sativa, resistência a herbicidas.

Recebido para publicação em 3.10.2012 e aprovado em 10.2.2013.

2 Engō-Agr ${ }^{\circ}$, Dr.,Pós-Doutorando no Dep. de Fitotecnia, Universidade Federal de Pelotas - UFPel, bolsista CAPES/PNPD, Caixa Postal, 354, 95015-560 Pelotas-RS, <caduschaedler@yahoo.com.br>; ${ }^{3}$ Engo-Agr ${ }^{\circ}$, Ph.D., Pesquisador da Epagri/Estação Experimental de Itajaí-SC; ${ }^{4}$ Eng ${ }^{0}-A_{g r}{ }^{0}$, Professor do Dep. de Fitossanidade, UFPel, Pelotas-RS; ${ }^{5}$ Eng ${ }^{\mathrm{a}}$-Agr ${ }^{\mathrm{a}}$, Professora, Universidade de Caxias do Sul, Vacaria-RS; ${ }^{6}$ Eng ${ }^{-}-A g r{ }^{0}$, Dr., Dep. de Fitossandidade, UFPel, Pelotas-RS. 


\section{INTRODUCTION}

The weed Fimbristylis miliacea, popularly known as globe fringerush, is native to tropical America, and in Brazil it is more frequent on the coast of the south region, yet it is also found in other regions such as the Amazon (Kissmann, 2007). This species is a major weed in paddy rice fields in the State of Santa Catarina (SC), and it may cause severe yield losses if not adequately controlled (Noldin et al., 2002).

To control F. miliacea in rice fields, ALS inhibitors are among the most used herbicides. However, after years of continuous use, the control of $F$. miliacea became ineffective due to the fact that some populations do not respond to the action of these herbicides. The first case of $F$. miliacea resistant to ALS inhibitors was observed in 2001 in Santa Catarina (Noldin et al., 2002). Since then, new cases have arisen with cross-resistance, i.e., resistance to different ALS-inhibiting chemical groups (Schaedler et al., 2011a).

In general, weed resistance to herbicides has not been associated with the reduced adaptive value of the resistant biotype. Under competition-free conditions, Kochia scoparia genotypes resistant and susceptible to herbicides of the sulphonylurea chemical group had similar growth and seed germination. However, in terms of competition, the behavior of genotypes reduced the shoot dry weight in interspecific competition more than in intraspecific (Thompson et al. 1994). A comparison of weed development in the absence of competition is crucial to estimate the ecological adaptability of biotypes resistant and susceptible to herbicides (Gray et al., 1995; Christoffoleti et al., 1997). For Lolium multiflorum (ryegrass), sensitive to the herbicide glyphosate (Vargas et al., 2005), and Lactuca serriola (prickly lettuce), sensitive to sulphonylureas (Alcocer-Ruthling et al., 1992), the susceptible biotypes produced a higher amount of dry matter than the resistant ones.

Studies that compared the relative growth and seed germination of Bidens subalternans (beggarticks) biotypes susceptible and resistant to ALS inhibitors under different temperature conditions showed no difference in relative growth rate among the biotypes studied, but the germination rate of the resistant biotype was lower than that of the susceptible population (Lamego et al., 2011). Rice cultivars tolerant to herbicides of the imidazolinone group with mutations in the ALS gene had faster germination compared to non-tolerant cultivars (Goulart et al., 2011).

Knowledge of the biological characteristics between resistant and susceptible biotypes is a fundamental assumption to define their competitive ability, and it can thereby assist in the choice of the management methods. Weeds usually germinate faster because their seeds are small; thus, they usually germinate near the soil surface, at a depth of up to $1 \mathrm{~cm}$ (Fischer $\&$ Miles, 1973). In a study evaluating the germination of $F$. miliacea at different depths and the duration of the water blade (Begum et al. 2006), the authors showed that the depth of the seeds of $F$. miliacea at soil associated with the height of the water blade are forms of efficient management in paddy rice fields to suppress the emergence and growth of this species.

A major concern associated with weed resistance to herbicides is that resistant biotypes may present higher adaptive value than that of susceptible ones, resulting in a greater potential for competition and invasiveness (Ellstrand, 1999). Knowledge of the physiological characteristics of resistant and susceptible biotypes is crucial to understand and define the competitive ability of a species and may, therefore, assist in the preparation and use of management methods. Therefore, this study hypothesizes that biotypes of $F$. miliacea susceptible and resistant to ALS inhibitors have different adaptive values when grown in the absence of competition and selection agent (herbicide). The objective of this study was, thus, to evaluate and compare the analysis of growth, characteristics of germination and seed mass of biotypes of F. miliacea susceptible and resistant to ALS inhibitor herbicides under controlled and uncompetitive conditions.

\section{MATERIAL AND METHODS}

Seeds of resistant biotypes of $F$. miliacea were collected in the county of Forquilhinha (SC), in rice fields properties were ALSinhibiting herbicides had been applied for at 
least ten consecutive years (FIMMI 10 28.47'912" S; 49॰26’528” W and FIMMI12 $\left.28^{\circ} 47^{\prime} 881^{\prime \prime} \mathrm{S} ; 4^{\circ} 33^{\prime} 971^{\prime \prime} \mathrm{W}\right)$. Seeds of a susceptible population, washarvested in the town of Agronômica (SC), in an area where ALS rice herbicide had never been applied (FIMMI 13 - 27¹6’978” S; 49॰44’776” W). To confirm resistance, pyrazosulfuron-ethyl (Sirius $\mathbb{R} 250$ SC - Iharabras) at a dose of $17.5 \mathrm{~g}$ a.i. ha $\mathrm{a}^{-1}$ was applied to seedlings of the resistant and susceptible biotypes. The herbicide was applied when the seedlings were at the six-leaf stage, using a $\mathrm{CO}_{2}$-pressurized backpack sprayer with a flow rate of $150 \mathrm{~L} \mathrm{ha}^{-1}$. Resistance was confirmed in a preliminary study, where GR50 (dose required for 50\% reduction of dry weight) of 56.4 and 690.16 was observed for biotypes FIMMI 10 and FIMMI 12, respectively, while the RF (resistance factor), calculated by dividing the GR50 of the resistant biotype by the GR50 of the susceptible population, was 46.2 and 565.6 for the biotypes FIMMI 10 and FIMMI 12, respectively (Schaedler, 2011b).

\section{Experiments to determine relative growth rate}

Two experiments were conducted in a greenhouse in the year 2008/09 (experiment 1) and repeated in 2009/10 (experiment 2). Each experimental unit consistedof a $3.5 \mathrm{~L}$ plastic pots filled with sieved soil from horizon A of a paddy field. This soil is classified as Lowland Solodic (Mapping Unit of Pelotas), with the following characteristics: water $\mathrm{pH}(1: 1)=5.1$; CTC $\mathrm{pH} 7=5.4 \mathrm{cmol}_{\mathrm{c}} \mathrm{dm}^{-3}$; organic matter $=1.2 \%$, clay $=15 \%$; texture $=4, \mathrm{Ca}=1.8 \mathrm{cmol}_{\mathrm{c}} \mathrm{dm}^{-3}$; $\mathrm{Mg}=1 \mathrm{cmol}_{\mathrm{c}} \mathrm{dm}^{-3} ; \mathrm{Al}=0.2 \mathrm{cmol}_{\mathrm{c}} \mathrm{dm}^{-3}, \mathrm{P}=$ $4.3 \mathrm{mg} \mathrm{dm}^{3}$; and $\mathrm{K}=30 \mathrm{mg} \mathrm{dm}^{-3}$.

The pots were perforated at the bottom and placed in a plastic tray containing water in order to irrigate by capillarity. The seeds of F. miliacea, susceptible and resistant to ALS inhibitors, were seeded at densities higher than desired, with subsequent thinning to remove the excess of plants, keeping one plant per pot.

The experimental design was completely randomized with four replicates. The treatments consisted of plants of biotypes resistant (FIMMI 10 and FIMMI 12) and susceptible (FIMMI 13) to ALS inhibitors and sampling times $(21,28,35,42,49,56,69$ days after emergence - DAE and flowering), resulting in a $3 \times 8$ factorial arrangement. The variables evaluated in each collection were: leaf area (LA), shoot dry weight (SDW) and root dry weight (RDW). LA was determined with a LI-COR leaf area meter, model Area Meter 3100C. SDW and RDW were quantified with a precision balance after the material was dried in an oven at a temperature of $60^{\circ} \mathrm{C}$, until constant weight. Besides, growth rate (GR) was calculated in g plant $^{-1}$ day $^{-1}$, determined by the ratio between SDW and number of days of plant growth.

Data were analyzed for their homogeneity and subsequently submitted to analysis of variance by the $F$ test $(p \leq 0.05)$ for both individual effects of factors as well as for interaction effects. The treatment means were compared by applying the LSD test ( $p \leq 0.05)$, and the data were fit to a three-parameter sigmoidal equation (Equation 1), as follows:

$$
Y=\frac{a}{1+\exp ^{(-(x-x a) / b)}}
$$

where $Y=$ dependent variable (LA, GR, SDW or RDW); $x=$ independent variable (DAE); $a=$ the difference between the maximum and minimum asymptotes; $b=$ slope of the curve, and $x a=$ days after emergence corresponding to $50 \%$ of the yield of the variable dependent of the value of the maximum asymptote $(a)$.

\section{Germination speed}

The study was conducted in a BOD growth chamber and aimed to provide information about the speed of germination of biotypes FIMMI 10, FIMMI 12 and FIMMI 13. The experiment was conducted in 2008 in a completely randomized design with five replicates. Each experimental unit consisted of a petri dish, with germitest paper, in which 50 seeds were evaluated. Germination speed was calculated based on agronomic criteria, which consisted of the daily count of germinated seeds until the fifteenth day after sowing. A seed was considered to be germinated when its radicle and/orshoots were longer than $2 \mathrm{~mm}$. 
The calculation of the germination speed index (GSI) used the equation proposed by Maguire (1962):

$$
I V G=G_{1} / D_{1}+G_{2} / D_{2}+\ldots G_{n} / D_{n}
$$

where $G_{1}=$ the number of seeds germinated on day one; $G_{\mathrm{n}}=$ cumulative number of germinated seeds on the fourteenth day; $D_{1}=$ first day count; $D_{n}=$ last day count.

\section{Germination and seed weight}

Germination percentage was determined in a Petri dish with germitest paper, with 50 seeds. Treatments were arranged in a factorial design, where factor A consisted of biotypes (FIMMI 10, FIMMI 12 and FIMMI 13) and factor B compared the effect of soaking the seeds in conditions of presence and absence of cold, aimed at overcoming seed dormancy. To establish the temperature condition, the soaked seeds were maintained at room temperature $\left(25^{\circ} \mathrm{C}\right)$ or in a refrigerator at $6 \pm 2{ }^{\circ} \mathrm{C}$ for 72 hours and then taken to BOD under conditions of $25^{\circ} \mathrm{C}$ and a photoperiod of 14 and 10 hours of light and dark, respectively. The variable assessed was percentage of germination at 10 days.

For the second study, conducted in 2010, eight replicates of 100 seeds of each biotype were separated and counted and then weighed on a precision balance, and the arithmetic mean was calculated. Therefore, the data were multiplied by 10 to represent the weight of a thousand seeds in grams. The data of variable weight of a thousand seeds were analyzed for their homogeneity and subjected to analysis of variance $(p \leq 0.05)$, and the means were compared by the LSD test ( $\mathrm{p} \leq 0.05)$.

\section{RESULTS AND DISCUSSION}

\section{Relative growth rate}

The variables LA, GR, SDW and RDW showed interaction between the factors tested for evaluation periods and biotypes $\mathrm{R}$ and $\mathrm{S}$ (Figure 1). The data conformed to the threeparameter sigmoidal model. There was no difference between biotypes for the first seven seasons of evaluation in any of the variables tested. However, for the last time of assessment, at early flowering, the biotypes showed differences in all variables. For the variable LA, the susceptible biotype FIMMI 13 showed a higher value when compared with the resistant biotype FIMMI 12, but the resistant biotype FIMMI 10 showed intermediate values and did not differ between biotypes FIMMI 13 and FIMMI 12.

The biotype FIMMI 13 had higher GR than the resistant biotypes. In absolute mean values, GR for the susceptible biotype was 13 and $15 \%$ higher than that of the resistant biotypes FIMMI 10 and FIMMI 12, respectively (Figure 1). These results are different from those reported by Dal Magro (2009), where the biotypes of Cyperus difformis susceptible and resistant to ALS-inhibiting herbicide pyrazosulfuron showed no differences for the variable GR.

For the variable SDW, similarly to variable GR, there were differences between the biotypes tested: SDW was higher for the susceptible biotype compared to the resistant biotypes FIMMI 10 and FIMMI 12, and these did not differ. The variable SDW is in important attribute for evaluating the growth of a plant and it is indicative of competitive ability (Gaudet \& Keddy, 1988).

Most studies that have evaluated morphological characteristics such as indicators of growth take into account indicators of shoot growth, since studies evaluating the root system usually are cumbersome and difficult to perform in the field. In this study, the resistant biotype FIMMI 12 showed the greatest RDW compared to the others, in the last assessment period.

In a study of compartmentalization, which evaluated the competition for environmental resources located above and below the soil surface, biotypes of $F$. miliacea susceptible and resistant to ALS inhibitors showed differential behavior when in competition with rice and between biotypes (Schaedler et al., 2011). These authors evaluated the dry weight of roots and found that the resistant biotype had a higher value compared to the susceptible biotype, in competition with rice for light use. However, when in competition for soil resources (especially nutrients), the susceptible biotype showed greater root mass. 

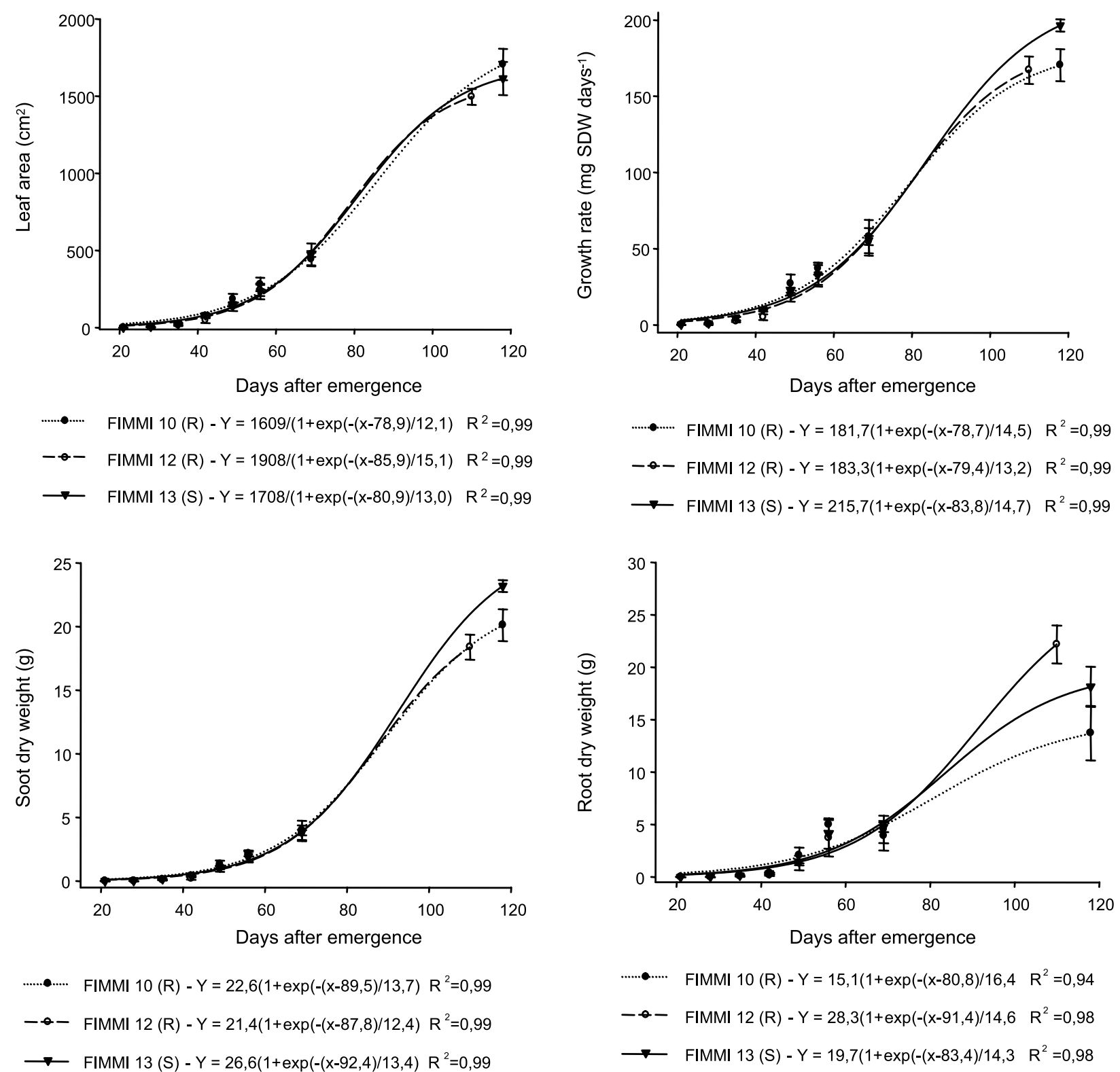

The dots represent the mean values of the replicates, and the vertical bars, the confidence intervals.

Figure 1 - Leaf area, growth rate, shoot dry weight and root dry weight of $F$ miliacea resistant and susceptible to ALS inhibitor herbicides - 2008/09 and 2009/10.

Moreover, the results observed for Bidens subalternans (Lamego et al., 2011), Kochia scoparia (Thompson et al., 1994) and Sagitaria montevidensis (Rampelottiet al., 2003), resistant and susceptible to ALS-inhibiting herbicides, showed identical growth characteristics, unlike the results of this study. For these authors, the results show that there is no penalty to the resistant biotype as for the adaptive value, caused by herbicide resistance.

It should be noted that the results of this study confirm the hypothesis that biotypes of F. miliacea resistant to the enzyme ALS showed different adaptive value when compared with the susceptible biotype, as biotypes showed 
differences in the variables LA, GR, SDW and RDW.

\section{Germination speed}

There was variation in germination speed between biotypes $\mathrm{R}$ and $\mathrm{S}$ of $F$. miliacea (Figure 2). The susceptible biotype FIMMI 13 showed higher germination speed index (GSI) compared with the resistant biotypes FIMMI 10 and FIMMI 12, but these did not differ statistically.

Studies undertaken with rice show that rice cultivars tolerant to the imidazolinone group with mutations in the ALS gene showed faster germination compared with susceptible cultivars (Goulart et al., 2011). According to these authors, the results showed that the faster germination for tolerant cultivars may have different consequences in the establishment and initial competition with red rice.

GSI was determined only in laboratory conditions; the results might be different in a greenhouse or field because the availability of water and air temperatures and soil is generally lower than those observed in a controlled environment. Size (starch reserves) and physiological quality (vigor) of the seeds are factors that may influence germination. Generally, seeds that have more vigor can germinate and emerge more quickly under adverse conditions (Vieira \& Carvalho, 1994).

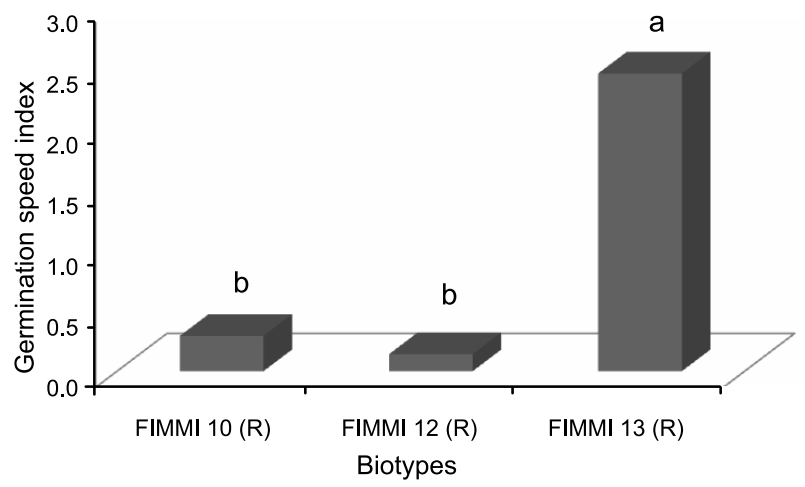

Overlapping bars with different letters by the LSD test $(p \leq 0.05)$.

Figure 2 - Germination speed index of R and S biotypes of F. miliacea until the fifteenth day after sowing, according to the equation by Maguire (1962)

\section{Germination and seed weight}

The comparison of the germination of seeds of biotypes of $F$. miliacea showed that the susceptible biotype had a higher percentage compared to the resistant ones (Figure 3). The comparison between soaking temperatures showed that for the resistant biotype FIMMI 10 and the susceptible one (FIMMI 13), soaking the seeds in cold condition reduces germination, while for the resistant biotype FIMMI 12, the soaking temperature does not modify the germination percentage. These results may allow the implementation of management strategies, e.g., the use of rice cultivars that have high speed emergence and growth rate, or the use of herbicides with different mechanisms of action in order to reduce the occurrence of the resistant FIMMI biotype in irrigated rice fields.

The thousand seed weight of both resistant biotypes was higher than that of the susceptible biotype (Figure 4). Although the resistant biotypes had higher seed weight, this feature does not seem to represent an advantage, since in the study of the adaptive values of these biotypes, the susceptible one showed a different behavior.

In this study, the biotypes of $F$. miliacea resistant and susceptible to ALS-inhibiting herbicides showed differences in their adaptive values at early flowering, but this was not observed at the early stages of development. In general, the susceptible biotype FIMMI 13 showed higher values for the variables evaluated compared to the resistant biotypes. The differences between biotypes for the two variables studied may be due to physiological changes in the function of ALS mutation, which makes herbicides resistant. In a study by Tardif et al. (2006), it was found that there were differences in adaptive values between the biotypes of Amaranthus powellii resistant and susceptible to ALS inhibitors. These authors also observed mutation in the genes of enzyme ALS in the position Trp574Leu, where the observed pleiotropic effects are directly associated with the mutation. This penalty was attributed to reduced competitiveness of the resistant biotype at the early stages of development. 


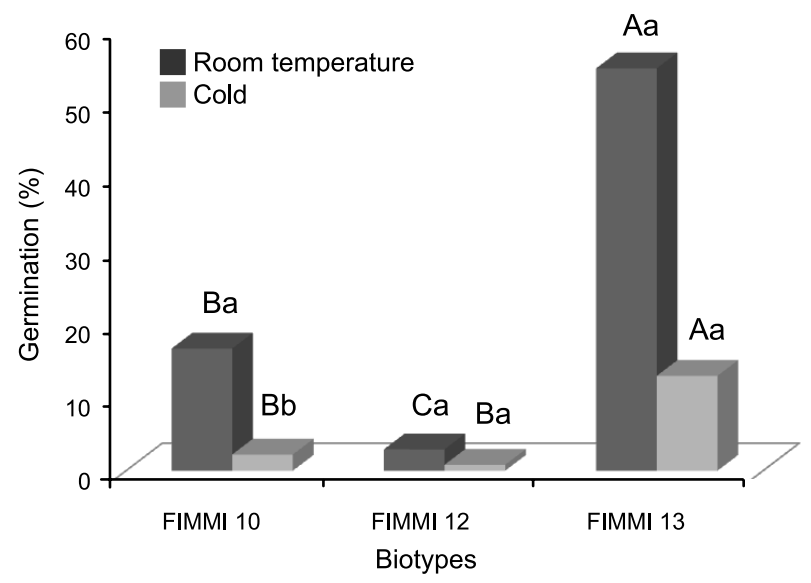

Uppercase and lowercase letters compare differences between biotypes and germination temperatures, respectively, by the LSD test $(\mathrm{p} \leq 0.05)$.

Figure 3 - Germination percentage of the biotypes of $F$. miliacea resistant and susceptible to ALS inhibitors - 2008.

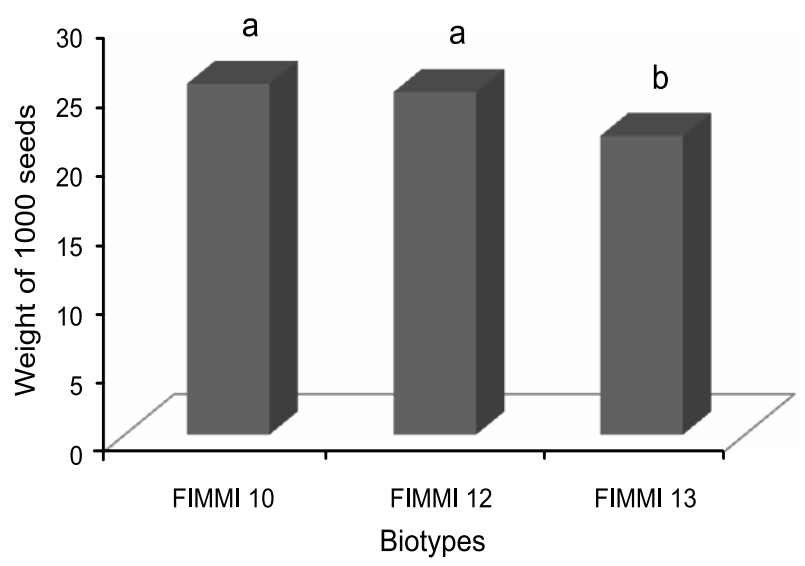

Overlapping bars with different letters by the LSD test ( $\mathrm{p} \leq 0.05$ ), 2010 .

Figure 4 - Mass of a thousand seeds of F. miliacea resistant (FIMMI 10 and FIMMI 12) and susceptible (FIMMI 13) to ALS inhibitors.

Although the biotypes of this study have been collected and stored in a similar way, it cannot be concluded that the difference in the adaptive value was a physiological penalty of a genetic nature for resistance. Experiments such as the evaluation of the gene of the ALS enzyme among biotypes are still needed to clarify this issue. On rice farms, where there are resistant populations of $F$. miliacea, rice production is significantly reduced due to lack of control of this weed. Integrated weed management, such as the use of herbicides with different mechanisms of action and the use of more competitive rice cultivars can be considered an effective strategy for managing FIMMI populations resistant to ALS inhibitors.

The studies show that biotype FIMMI 12 showed higher leaf area, shoot dry weight and root dry weight compared to the resistant biotype FIMMI 10 and compared to the susceptible FIMMI 13, just at flowering. The susceptible population FIMMI 13 showed a higher germination speed index and higher germination percentage when compared with the resistant biotypes. On the other hand, the resistant biotypes FIMMI 10 and 12 FIMMI had higher seed weight.

\section{ACKNOWLEDGMENTS}

The authors would like to thank CNPq (National Council for Scientific and Technological Development) for the Ph.D. scholarship granted to the first author, and the Department of Plant Protection, Federal University of Pelotas, for the infrastructure and support offered to this research study.

\section{LITERATURE CITED}

ALCOCER-RUTHLING, M.; THILL, D.C.; SHAFII, B. Differential competitiveness of sulfonylurea-resistant andsusceptible prickly lettuce (Lactuca serriola). Weed Technol., v. 6, n. 2, p. 303-309, 1992.

BEGUM, M. et al. The effects of sowing depth and flooding on the emergence, survival, and growth of Fimbristylis miliacea (L.) Vahl. Weed Biol. Manag., v. 6, n. 3, p. 157-164, 2006.

CHRISTOFFOLETI, P. J.; WESTRA, P.; MOORE, F. Growth analysis of sulfonylurea-resistant and susceptible kochia (Kochia scoparia). Weed Sci., v. 45, n. 5, p. 691-695, 1997.

DAL MAGRO, T. Caracterização de biótipos de Cyperus difformis L. resistente e suscetível a herbicidas inibidores da enzima ALS. 2009. 99 f. Tese (Doutorado em Fitossanidade) - Universidade Federal de Pelotas, Capão do Leão, 2009. 
ELLSTRAND, N. C. Gene flow and introgression from domesticated plants into their wild relatives. Ann. Rev. Ecol. Syst., v. 30, p. 539-563, 1999

FISCHER, R. A.; MILES, R. E. The role of spatial pattern in the competition between crop plants and weeds. A theoretical analysis. Mathem. Biosci., v. 18, n. 3-4, p. $335-350,1973$.

GAUDET, L. C.; KEDDY, P. A. A comparative approach to predicting competitive ability from plants traits. Nature, v. 334, n. 6179 , p. $242-243,1988$

GOULART, I. C. G. R.; MATZENBACHER, F. O.; MEROTTO JR., A. Differential germination pattern of rice cultivars resistant to imidazolinone herbicides carrying different acetolactate synthase gene mutations. Weed Res., v. 52, n. 3 , p. $224-232,2011$

GRAY, J. A.; STOLTENBERG, D. E.; BALKE, N. E. Productivity and intraspecific competitive ability of a velvetleaf (Abutilon theophrasti) biotype resistant to atrazine. Weed Sci., v. 43, n. 4, p. 619-626, 1995.

KISSMANN, K. G. Plantas infestantes e nocivas. 3.ed. São Paulo: Basf Brasileira, 2007. CD ROM.

LAMEGO, F. P.; VIDAL, R. A.; BURGOS, N. R. Competitiveness of ALS inhibitors and susceptible biotypes of greater beggarticks (Bidens subalternans).

Planta Daninha, v. 29, n. 2, p. 457-464, 2011.

MAGUIRE, J. D. Speed of germination-aid in selection and evaluation for seedling emergence and vigor. Crop Sci., v. 2, n. 1, p. $176-177,1962$.

NOLDIN, J. A.; EBERHARDT, D. S.; RAMPELOTTI, F. T. Fimbristylis miliacea (L.)Vahl resistente a herbicidas inibidores da ALS em Santa Catarina. In: CONGRESSO BRASILEIRO DA CIÊNCIA DAS PLANTAS DANINHAS, 23., 2002, Gramado. Resumos... Londrina: SBCPD/Embrapa Clima Temperado, 2002. p. 199
RAMPELOTTI, F. T. et al. Análise de crescimento deecótipos de sagitária (Sagittaria montevidensis) resistente e suscetível a herbicidas inibidores da ALS. In: CONGRESSO BRASILEIRO DE ARROZ IRRIGADO, 3., 2003, Balneário Camboriú. Anais... Itajaí: Epagri, 2003. p. 483-485.

SCHAEDLER, C. E. Resistência de Fimbristylis miliacea (L.) Vahl aos herbicidas inibidores da enzima ALS. 2011. $117 \mathrm{f}$. Tese (Doutorado em Fitossanidade) - Faculdade de Agronomia Eliseu Maciel, Universidade Federal de Pelotas, Pelotas, 2011a.

SCHAEDLER, C. E. et al. Cross-resistance patterns of acetolactate synthase (Als) inhibitor-resistantglobe fringerush (Fimbristylis miliacea) biotypes in Southern Brazil. In: $<$ http://wssaabstracts.com/public/4/abstract-291.html>, WEED SCIENCE SOCIETY OF AMERICAANNUAL MEETING, Portland. Abstracts... Portland: 2011.

SCHAEDLER, C. E. Competitive ability of ALS-resistant Fimbristylis miliacea with rice. In: $<$ http://www.swss.ws/ NewWebDesign/Proceedings/Archives/2011\%20ProceedingsSWSS.pdf $>$. SOUTHERN WEED SCIENCE SOCIETY, v.64, San Juan, Puerto Rico, Abstracts... 2011b.

THOMPSON, C. R.; THILL, D. C.; SHAFII, B. Growth and competitiveness of sulfonylurea-resistant and -susceptible kochia (Kochia scoparia). Weed Sci., v. 42, n. 2, p. 172-179, 1994.

TARDIF, F. J.; RAJCAN, I.; COSTEA, M. A mutation in the herbicide target site acetohydroxyacid synthase produces morphological and structural alterations and reduces fitness in Amaranthus powellii. New Phytol., v. 169, n. 2, p. 251-264, 2006.

VARGAS, L. et al. Alteração das características biológicas dos biótipos de azevém (Lolium multiflorum) ocasionada pela resistência ao herbicida glyphosate. Planta Daninha, v. 23, n. 1, p. 153-160, 2005.

VIEIRA, R. D.; CARVALHO, N. M. Testes de vigor em sementes. Jaboticabal: FUNEP, 1994. 164 p. 